\title{
The Meaning of Private in an Age of Surveillance
}

\author{
William W. Bostock ${ }^{1, *}$ \\ ${ }^{1}$ School of Social Sciences, University of Tasmania, Sandy Bay, Tasmania, Australia \\ *Correspondence: School of Social Sciences, University of Tasmania, Private Bag, Sandy Bay, Tasmania, Australia \\ 7000. E-mail: bostock@utas.edu.au
}

Received: November 14, 2020 Accepted: December 28, 2020 Online Published: January 15, 2021

doi:10.5430/wjss.v8n1p67 URL: https://doi.org/10.5430/wjss.v8n1p67

\begin{abstract}
The private has great significance for the individual as it is where identity is stored. However, the private comes at a cost, particularly in a time of mass surveillance, which is heightened by the present Coronavirus pandemic, and is becoming more and more rare as individuals seek security. At the collective level, whole societies are moving towards privatisation, as the private gives relief from increased surveillance by media, governments and informed individuals and organisations, thus allowing more operational flexibility. Private and public are significant as polar ends of a spectrum in which individuals and collectivities must position themselves on a wide range of issues while maintaining identity. As shown in the case of airport privatisation, the determining process has been influenced by cultural factors such as a desire to avoid surveillance and scrutiny, sociological factors such as contagion, and political factors such as convergence. In all areas of human activity, a rebalancing between private and public may be necessary, and a transdisciplinary approach would be appropriate.
\end{abstract}

Keywords: private, public, identity, surveillance, contagion, convergence, pandemic

\section{Introduction}

\subsection{The Meaning of Private}

The word private comes from the Latin privatus, meaning withdrawn from public life, peculiar to oneself, or a person in private life. Private thus describes one's sense of uniqueness or identity, as distinct from others. Private also means distinct from holding public or official position, whilst private ownership refers to distinct possession by an individual or group of individuals of assets where there is no sense of public ownership.

There is private ownership of the goods and services that can also be called private property and there is also private ownership at the collective level such as an enterprise where a business is privately owned and not subject to a high degree of state control, or a private institution such as a private school or university, a private hospital or a private sporting body such as a golf club. In that the concept of private expresses, maintains and affirms a unique sense of identity, it is enduring and universally appealing. Private ownership greatly simplifies responsibilities so that when surveillance by the world outside becomes too problematic, confusing and unsupportable, the individual or the collectivity will desire a retreat to the private as an ultimate reserve of identity (Alford, 1988, p. 587).

Private contrasts with public, which comes from the Latin publicus, of the people. Private and public together form a spectrum, being at polar ends from closed and exclusionary thought and behaviour to that which is open and available for recognition and inspection. At either end of the spectrum, there still remains the motivation to satisfy the need for meaning, which is the basic unit of society (Lane, 2020).

\subsection{The Private in Literature}

To observe how this works in practice, one can turn to literature and other forms of artistic expression. A classic example of this is the novel Nineteen Eighty-Four by George Orwell (Orwell, 2005), first published in 1949, and adapted for radio, television, theatre and film, notably in the celebrated film 1984 directed by Michael Radford and starring John Hurt, Richard Burton, Suzanna Hamilton and Cyril Cusack. The relevance of Nineteen Eighty-Four lies in the fact that many (but not all) aspects of life as portrayed in the novel have become a reality in the present-day world. 
In the novel, a super-state is led by an all-powerful, remote and mysterious party leader who is known only by the name of Big Brother. Control over its individual members is absolute, enforced at the level of thought as well as behaviour by the Thought Police. All aspects of life are monitored by surveillance with equipment that was advanced for its day consisting of two-way cameras and screens and recording devices. Language, memory, thought and logic are manipulated to extend and maintain control, while expressions of free thought are severely punished. In this super-state, any tendency towards private life, such as individualism or eccentricity, which is called ownlife in the official language of Newspeak, leads to arrest and re-education, and ultimately torture and death. When the novel's hero Winston Smith is finally arrested and imprisoned for the crime of private thought and behaviour, he is told through a remote speaker box "6079 Smith, W. Uncover your face. No faces covered in the cells." (Orwell, 2005, p. 268). As Smith had already remarked, privacy is a very valuable thing (Orwell, 2005, p. 159).

\subsection{The Private in an Age of Surveillance}

Surveillance and control by the state and other agencies in the modern world are rapidly expanding. The outbreak of the Coronavirus pandemic in 2020 has led to dramatic increases in control by states over their populations, in the form of surveillance, lockdowns and closure of borders in order to maintain physical and mental health (Sadati, Lankarani \& Lankarani, 2020). However, the appeal of the private is still great. The ubiquity of mass surveillance is a result of its benefits is also explained in terms of preventing and detecting crime (Taylor, 2002, p. 66), but the benefits of surveillance come at a cost in privacy. These costs are widely recognised by legislative authorities, so that a balance must be made between rights to privacy against social benefits (Taylor, 2002, p. 80). Another aspect of mass surveillance is the extension of technical surveillance into the normative area of social control, especially the maintaining and augmenting of divisions in society (Coleman, 2003).

In addition to state-run surveillance, there is covert surveillance by many different types of organisation (Coleman, 2003), and the fact that millions of individuals voluntarily sacrifice their privacy through the use of social media such as Facebook, Twitter, MySpace, or Orkut (Akram \& Kumar, 2017). Thus, because of the huge range of negative effects of the mass surveillance, which is an inevitable fact of modern society, there has been created an enormous desire for individual and group privacy. This could be seen as a retreat into private with the purpose of affirming identity through freedom of action.

\section{Private at the Individual Level}

\subsection{The Underground Restaurant}

There is an increasingly popular but illegal practice in New York City and some other cities of the offering of dinners in private residences by individuals who are in possession of varying degrees of experience and skill in food preparation and presentation. These dinners are attended by guests who pay to visit so-called "underground restaurants" or "secret supper clubs", thus providing a practical example of the private/public dichotomy (Koch, 2019). While proving popular, such "restaurants" are operating outside the framework of public protection normally provided by the state or municipal authorities. The protections that normally cover food safety, health and hygiene, liquor licensing, fire safety and contribution to tax revenue raising are simply not present. An individual attending an underground restaurant is therefore exchanging the protection of a public restaurant for the appeal of a possibly more interesting and less expensive private dining experience. This type of restaurant is but one of many types of peer-to-peer economic activity facilitated by the internet and which is notably present in such areas as transport and accommodation, as part of the so-called "gig economy", where a high proportion of the workforce is casualised (Manyika, et.al., 2016).

\subsection{The Gated Residential Community}

Gated communities are not a new development, rather they are an ancient solution to the problem of the need to ensure security, for an individual and for a community. The development of the modern gated residential community provides an example of the appeal of the private at community level. The gated community can be defined as a planned neighbourhood that is surrounded by a boundary fence or wall separating it from its environs. Entry is controlled by security staff, gates and/or electronic entry systems (Bowers \& Manzi, 2006).

The walls of a gated community are not necessarily physical. In the Western Cape of South Africa, the semi-autonomous community of Oranje has been founded with purpose of preserving the language of Afrikaans, by making the language the means of communication in schools, churches, public meetings and official administration (de Beer, 2006, p. 110). Similar gated community are now widespread in many forms in many countries of the world, and can be seen as a means of preserving private identity, culture, lifestyle and economic position at community 
level.

\subsection{The Private Car}

The private car is often seen as socially problematic, being seen as a cause of pollution, climate change, urban congestion, and health problems such as heart attacks (Docherty \& Shaw, 2008). Many experts propose the use of alternative transport modes such as walking, cycling and public transport as a solution of the problem of finding a solution to urban transport (Newman, 2003). However, despite all the problems it brings, the private car remains a source of psychological appeal (Kent, 2014). The private car offers flexibility and comfort, with the possibility of listening to music and discussion, and can even assist in the process of parenting (Kent, 2014). To this, one could add that the private car can be a vehicle for identity, carrying for its owner a sense of identity, where, as already noted, meaning is the basic unit of society (Lane, 2020).

The implication for policy is that while public transport is favoured as a solution to urban transport needs, the private car is likely to remain the preferred option for many of its citizens (Kent, 2014).

\section{Private at the Collective Level}

\subsection{The Private/ Public Dichotomy}

Though brought sharply into focus by the development of electronic media, the private/public dichotomy is not at all new, and in fact it has been a major dichotomy in political thought since antiquity (Bobbio, 1989). All individuals and collectivities must make decisions as to the desirability of private or public ownership of assets and enterprises. These decisions are often influenced by ideology, especially as it was in the time of the Cold War interface between the west, in particular the United States, and the Soviet bloc. Whilst the dichotomy is often simplified as "private is good/public is bad", or "private is bad/public is good" (Morgan \& Allington, 2003), under examination, this characterisation of the decision-making process has been described by one commentator as "equally daft" (Le Vay, 2017).

In the ancient world, public enterprises existed, such as that which administered the supply of grain in the Roman Empire, while private enterprise was the organising principle for many aspects of organisation in China under the Han and Ming dynasties. Contracting to private individuals and groups was also widespread in Europe: in 1492, Queen Isabella of Spain outsourced the exploration of the Western hemisphere to a Genoese contractor, Christopher Columbus, while England subcontracted a private army of Hessian mercenaries to fight against the American colonials in the American War of Independence (Savas, 2010).

\subsection{The Private at Collective Level: Industry in the Post World War II Era}

In the Post World War II era, many state enterprises were put into private ownership by many states in a process called privatisation, often motivated by a sense of revulsion against the actions of states. In 1961, the Adenauer government of the Federal German Republic (West Germany) began a large-scale program of privatisation with the sale of its majority stake in Volkswagen and VEBA, the United Electricity and Mining Corporation. In 1978, China privatised land ownership by deregulation, whilst 1979 saw in Great Britain the election to government of the Thatcher Conservative government, who carried out the sale of such publicly-owned industries and corporations as telecommunication, the rail network, British Aerospace, Cable and Wireless, and airports (Megginson \& Netter, 1999).

The continuing appeal of privatisation is that it provides relief from scrutiny by outside bodies, in particular the media, and is thought to provide incentives that result in greater efficiency, especially through having greater freedom in matters of staffing. This is believed to occur because by introducing the concept of a market, which brings with it a possibility of bankruptcy, is creating a risk to which a publicly-owned enterprise is more or less exempt. An example of this can be found in the running of airlines. In the case of British Airways in the 1950's and 1960 's, their operating costs were made significantly higher by the imposition of a politically determined policy of "buying British" in regard to aircraft (Pryke, 1968, Domberger \& Piggott, 1984).

Political influence can lead to corruption on a large scale. However, corruption can also occur in the privatisation process where valuable enterprises and industries can be sold at greatly undervalued prices to those with connections to the political decision-makers. Corruption has a negative effect of undermining economic and organisational rationality in decision-making, and it can also bring a state of collective depression to an organisation and its surrounding society (Bostock, 2012).

The beneficial effects of market-driven decision-making were proclaimed by Margaret Thatcher, British Prime 
Minister 1979-1990, when she stated that "nobody bucks the market" (Thatcher, 2019). With the criterion of market performance, a privatised enterprise has greater freedom of action through reduced surveillance and an objective measure of responsibility. This process is aided also by a reduction of the power of public sector unions, a factor considered very important by the Thatcher government (Domberger \& Piggott, 1984). The implications for employment and the role of union power has made privatisation an ideological battleground in many industries in numerous countries, and sometimes countries fluctuate between privatisation and state ownership or nationalisation. In 1973, the new government of Pinochet in Chile re-privatised many of the industries that had been nationalised by the previous Allende government. When Chile entered a debt and repayments crisis in the early 1980's, these industries were renationalised again. In the mid 1980's, a second and more successful program of privatisation was commenced (Megginson \& Netter, 1999).

Another incentive for privatisation is also made on the on the reasoning that by vacating an area of administration, welfare services can be improved in such key areas as health and education. This movement resulting from privatisation has been described as welfare gravitation and has also been seen to operate between countries as well (Lin \& Mantin, 2015). Privatisation can also be considered a method of resolving environmental issues by taking them out of the public arena (Forsyth, 2005). Privatisation is thus be seen by some as an affirmation of the value of the private at the level of the enterprise, industry or society.

\subsection{The Inter-government Appeal of the Private}

It has long been recognised in group psychology that at the level of the group, the full range of human thought processes, emotions and responses, including aggression, as examined and hypothesised by psychologists, is accepted as a starting point. Wherever there is a collectivity, there will be a collective mental state, as large numbers of people come to share similar ontologies and emotions including fear. Le Bon, (2009), called this process contagion, in a similar way to a physical condition. In his classic study of the French revolution, Le Bon observed this process at work (Le Bon, 2009), and it is plausible to observe this process at inter-governmental level. When the results of the contagion process become accepted as normal, they become embodied in culture.

A current formulation of this process has been called convergence (Tovar \& Cardeñosa, 2003). As already noted, the modern world has seen fundamental change brought about by the information technology revolution. This, combined with the end of ideological confrontation between world powers (though not economic confrontation) and the rise to dominance of the English language brought with it an acceptance by world political leaders of the neoliberal economic paradigm, in a process called globalisation (Tovar \& Cardeñosa, 2003). The present situation could be described as one of globalised surveillance, greatly heightened by psychologically contagious fear of biological contagion in a pandemic (Sadati, et al., 2020).

\subsection{Private Airports}

An example of convergence is the privatisation of airports which has been adopted as a legitimate and desirable policy by more than 100 countries, while the share of Gross Domestic Product produced by state-owned enterprises across the board has dropped, for instance, it dropped from 9 per cent in 1978 to 6 per cent in 1994 (Megginson \& Netter, 1999).

The justification for airport privatisation is that passengers have more choice and enhanced service quality, however, the impacts of privatisation on airports and other aspects of the transport industry have not been consistently predictable (Estache \& Serebrisky, 2004). In some research, it was not surprisingly found that airports with the highest volume of traffic charge higher prices to airlines as did those not in competition with other modes of transport. In this connection, airports located on islands were noted to have imposed higher charges than continental airports which were in competition with other airports (Bel \& Fageda, 2010).

Cross-subsidisation from airport concessions is another factor influencing airport charges (Bilotkach, Clougherty, Mueller \& Zang, 2012). Airport privatisation has thus become a widely appealing paradigm, but in Asian countries and the United States, governments have often retained majority control, thus avoiding the severity of economic behaviour that can come from private ownership (Hooper, 2002).

The rationale of airport privatisation is the need to enhance investment and improve efficiency, but evidence of improved performance has not been conclusive (Graham, 2011). The chief executive and director-general of the International Air Transport Association (IATA), Alexandre de Juniac, has stated that airports performed better in public ownership and that IATA's member airlines are struggling with costs at privatised airports as widely dispersed as Paris, Sydney and Santiago. The same observer noted that those airports that regularly topped the survey of the world's highest performing airports, specifically Amsterdam, Dubai, Hong Kong, Seoul Incheon, and 
Singapore Changi, were all in public ownership (Australian Aviation, 2017, p. 16).

\subsection{Public Airports in the United States}

Although there is some support for the privatisation of American airports, mainly because it is claimed that they would be more passenger-friendly, the vast majority of American airports remain publicly owned and operated. In 2007, 63.9 per cent of commercial service airports were owned by local governments, and the rest by a single-purpose authority (Van Dender, 2006).

In a nation committed to the concept of the free market, relative scarcity of privatised airports is an interesting question (Principato, 2018). Among the factors put forward to explain this situation is that in the United States, airlines have for many decades played a key role in the management and financing in the operation of airports, unlike elsewhere (Bel \& Fageda, 2010). Airlines and other airport users have become accustomed to exercising a major influence in the management of airports and are reluctant to consider another business model. Another factor is the argument that US airports are currently managed in an efficient way, and therefore the perceived need for privatisation is much less pressing than in many other countries (Principato, 2018).

In addition, there is in the United States an intense level of competition between airports, and between air transport and other modes of transport, both of passengers and of freight, which means that airports must provide efficient and cost-effective service in a highly competitive market. Furthermore, US airports that are in the public ownership of local government, government departments or public authorities have the greater part of their operation contracted to private enterprise, which is providing a market-driven discipline (Vasigh \& Gordjidooz, 2006).

Even so, the privatisation of US airports is under active consideration by a Federal Aviation Authority Privatisation Pilot Program, but with opposition from the airlines, for the reasons discussed above (Principato, 2018).

\subsection{Private Airports in Australia}

In the early days of aviation in Australia, airfields were generally seen as part of the national defence infrastructure. A change occurred in 1987 when the Hawke Labor government created the Federal Airport Corporation (FAC) with responsibility to manage, operate and facilitate 22 major airports. This was an important part of the overall corporatisation of major government involvement in the Australian economy, along with the corporatisation of major utilities in telecommunications, water, gas, electricity, ports and harbours (Stevens, Baker \& Freestone, 2010). This was done with very little or no criticism by parliamentary Opposition, State governments, the media or the general public. After it came to power in 2002, the Howard Liberal-National Coalition government sold the airports at Melbourne (MEL), Brisbane (BNE) and Perth (PER) to consortia of private investment bodies specifically set up for the purpose, with Sydney (SYD) and then all other major airports soon following (Forsyth, 2005). After privatisation, the Federal government adopted a policy of minimal intervention in the running of airports, which was called a "light-handed approach", and with an added condition that the cross-ownership of airports be restricted.

Since privatisation, Australian airports have become the subject of strong concern and complaint by members of the public, the media, corporate users such as airlines, and international bodies, but not for the major part, political parties.

The Australian Competition and Consumer Commission (ACCC) is an important government agency tasked with providing regular reviews of industries, including in its scope the four major airports, SYD, MEL, BNE and PER. In its report for 2016/2017, the ACCC assessed selected airports for quality of service in a range of "very poor, poor, satisfactory, good or excellent" and found that PER and BNE were rated as "good", and SYD and MEL were rated as "satisfactory" (ACCC, 2018).

\section{Conclusion}

The meaning of the private is that it has enduring appeal to the individual and to the collectivity by providing relief from surveillance. This is because the private carries a reserve of identity, offering and affirming a sense of freedom of thought and action. The individual can position himself or herself on a private/public spectrum on any number of areas of life, but in times of surveillance and pandemic-induced anxiety, this is increasingly difficult. However, the private comes at a cost that an individual or society may not be prepared to pay, such as risk to health, loss of the security, and possibly even survival.

At the collective level, a group will position itself on a private/public spectrum on a wide range of issues. The appeal of the private at the collective level is freedom from surveillance, inspection and control, but this comes at a cost to the collectivity of reduced social responsibility. The decision is highlighted in the example of airport ownership, 
where in a process of convergence, private ownership is seen as favouring efficiency, but coming at a cost to be carried by consumers. Ultimately, positioning on the private/public spectrum on the full range of issues will require constant rebalancing. The positions taken will be of considerable significance in consequences and demand transdisciplinary analysis and research.

\section{References}

Akram, W., \& Kumar, R. (2017). A study on positive and negative effects of social media on society. International Journal of Computer Sciences and Engineering, 5(10), 351-354.

Alford, C. (1988). Mastery and Retreat: Psychological Sources of the Appeal of Ronald Reagan. Political Psychology, 9(4), 571-589.

Australia, ACCC, Australian Competition \& Consumer Commission (2018). Airport Monitoring Report, $2016,17$. Canberra: Australian Competition \& Consumer Commission.

Australia, Productivity Commission (2018). Economic Regulation of Airports, Issues Paper. Canberra, Productivity Commission.

Australian Aviation (2017). IATA boss says privatisation a failure. Pre-flight, December 16, 16.

Bel, G., \& Fageda, X. (2010). Privatization, regulation and airport pricing: an empirical analysis for Europe. Journal of Regulatory Economics, 37, 142-161. https://doi.org/10.1007/s11149-009-9110-7

Bilotkach, V., Clougherty, J. A., Mueller, J., \& Zhang, A. (2012). Regulation, privatization, and airport charges: panel data evidence from European airports. Journal of Regulatory Economics, 42(1), 73-94. https://doi.org/10.1007/s11149-011-9172-1

Bobbio, N. (1989). Democracy and Dictatorship: The nature and limits of state power. Minneapolis: University of Minnesota Press.

Bostock, W. (2012). The Effects of Corruption on the Collective Mental State of Organisations. Journal of Law and Social Sciences, 1(2), 64-73.

Bowers, B. S., \& Manzi, T. (2006). Private security and public space: new approaches to the theory and practice of gated communities. European Journal of Spatial Development, 22(1), 1-17.

Coleman, R. (2003). Images from a Neoliberal City: The State, Surveillance and Social Control. Critical Criminology, 12, 21-42. https://doi.org/10.1023/B:CRIT.0000024443.08828.d8

de Beer, F. C. (2006). Exercise in futility or dawn of Afrikaner self-determination: an exploratory ethno-historical investigation of Orania. Anthropology Southern Africa, 29(3-4), 105-114.

Docherty, I., \& Shaw, J. (Eds.). (2008). Traffic jam: ten years of 'sustainable' transport in the UK. Policy Press.

Domberger, S., \& Piggott, J. (1984). Privatization Policies and Public Enterprise: A Survey. Economic Record, 62(2), 145-162. https://doi.org/10.1111/j.1475-4932.1986.tb00891.x

Estache, A., \& Serebrisky, T. (2004). Where Do We Stand on Transport Infrastructure Deregulation and Public-Private Partnership? World Bank Policy Research Working Paper, 3356(July). https://doi.org/10.1596/1813-9450-3356

Forsyth, P. (2005). Airport Policy in Australia and New Zealand: Privatisation, Light-Handed Regulation and Performance. Conference: Comparative Political Economy and Infrastructure Performance: The Case of Airports, Fundación Rafael del Pino, Madrid, September 18-19. Retrieved from https://www.researchgate.net/profile/Peter_Forsyth/publication/228670208_Airport_Policy_in_Australia_and_ New_Zealand_Privatisation_Light_Handed_Regulation_and_Performance/links/00b7d527a8d4c9a928000000/ Airport-Policy-in-Australia-and-New-Zealand-Privatisation-Light-Handed-Regulation-and-Performance.pdf

Graham, A. (2011). The objectives and outcomes of airport privatisation. Research in Transportation Business Management, 1(1), 3-14. https://doi.org/10.1016/j.rtbm.2011.05.004

Hooper, P. (2002). Privatization of airports in Asia. Journal of Air Transport Management, 8(5), 289-300. https://doi.org/10.1016/S0969-6997(02)00009-1

Kent, J. L. (2014). Driving to save time or saving time to drive? The enduring appeal of the private car. Transportation Research Part A, 65, 103-115. https://doi.org/10.1016/j.tra.2014.04.009

Koch, R. (2019). Public, private, and the appeal to common good: Practices of justification in a peer-to-peer 
economy. Transactions of the Institute of British Geographers, 45(2), 392-405. https://doi.org/10.1111/tran.12345

Knill, C. (2015). Introduction, Cross-national policy convergence: concepts, approaches and explanatory factors. Journal of European Public Policy, 12(5), 764-774. https://doi.org/10.1080/13501760500161332

Lane, J-E. (2020). What Are the Basic Units of Society? A Micro Discussion. World Journal of Education and Humanities, 2(4), 41-44. https://doi.org/10.24908/ss.v1i1.3394

Lin, M., \& Mantin, B. (2015). Airport privatization in international inter-hub and spoke networks. Economics of Transportation, 4(4), 189-199. https://doi.org/10.1016/j.ecotra.2015.07.001

Le Bon, G. (2009). Psychology of Crowds (annotated). (First published 1895). London: Sparkling Books.

Le Vay, J. (2017). 'Public good, private bad' or 'private good, public bad': equally daft. Thoughts on Government. Retrieved from https://www.julianlevay.com/articles/public-good-private-bad-or-private-good-public-bad-equally-daft

Manyika, J., Lund, S., Bughin, J., Robinson, K., Mischke, J., \& Mahajan, D. (2016). Independent work: Choice, necessity, and the gig economy. McKinsey Global Institute, 2016, 1-16.

Megginson, W., \& Netter, J. (1999). From state to market: A survey on empirical studies on privatization. EconStor, Nota di Lavoro, 1, 1999. Retrieved from http://hdl.handle.net/10419/154955

Morgan, P., \& Allington, N. (2003). Private sector 'good', public sector 'bad'? Transformation or transition in the UK public sector? Scientific Journal of Administrative Development, 1(1), 22-53.

Newman, F. (2003). Walking in a historical, international and contemporary context. In Tolley, R., (Ed.), Sustainable transport: planning for walking and cycling in urban environments (pp. 48-58). Woodhead, Cambridge.

Nineteen Eighty-Four (1984). Film. Directed by Michael Radford. Virgin Films: London.

Orwell, G. (2005). Nineteen Eighty-Four. (First published 1949). Melbourne: Penguin.

Principato, G. (2017). This is why no airport privatization in the US. New Airport Insider, December 15, 2017. Retrieved from https://newairportinsider.com/airport-privatization-united-states/

Pryke, R. (1968). The Nationalised Industries, Policies and Performance since 1968. Oxford: Martin Robertson.

Sadati, A. K., B Lankarani, M. H., \& Bagheri Lankarani, K. (2020). Risk society, global vulnerability and fragile resilience; sociological view on the coronavirus outbreak. Shiraz E-Medical Journal Online ahead of Print, 21(4), e102263. https://doi.org/10.5812/semj.102263

Savas, E. (2010). Privatization and Public-Private Partnerships. New York: Chatham House.

Stevens, N., Baker, D., \& Freestone, R. (2010). Airports in urban settings: towards a conceptual model of interfaces in the Australian context. Journal of Transport Geography, 18(2), 276-284. https://doi.org/10.1016/j.jtrangeo.2009.05.007

Taylor, N. (2002). State Surveillance and the Right to Privacy. Survellance \& Society, 1(1), 66-85. https://doi.org/10.24908/ss.v1i1.3394

Thatcher, M. (2019). Wikiquote, Margaret Thatcher. Retrieved from https://en.wikiquote.org/wiki/Margaret_Thatcher/

Tovar, E., \& Cardeñosa, J. (2003). Convergence in Higher Education: Effects and Risks. Convergences 03, International Conference on the Convergence of Knowledge, Culture, Language and Information Technologies. Alexandria, Egypt, December 2-6, 2003. $\quad$ Retrieved from http://www.cfilt.iitb.ac.in/convergence03/all\%20data/paper\%20032-15.pdf

Vasigh, B., \& Gorjidooz, J. (2006). Productivity Analysis of Public and Private Airports: A Causal Investigation. Journal of Air Transportation, 11(3), 144-163.

Van Dender, K. (2006). Determinants of Fares and operating revenues at US airports. Journal of Urban Economics, 62(2), 317-336. https://doi.org/10.1016/j.jue.2006.09.001 


\section{Copyrights}

Copyright for this article is retained by the author(s), with first publication rights granted to the journal.

This is an open-access article distributed under the terms and conditions of the Creative Commons Attribution license (http://creativecommons.org/licenses/by/4.0/). 